International Journal on Design and Manufacturing Technologies, Vol.3, No.1, January 2009

\title{
ECOLOGICAL FOOTPRINT AS A TOOL TO MEASURE SUSTAINABILITY OF RURAL AREA - A CASE STUDY OF ANANGANALLORE PANCHAYAT VILLAGE, GUDIYATTAM BLOCK, TAMILNADU.
}

\author{
Narayana K.A. , Sekar S.P. ${ }^{2}$, Venkatesan M. $^{3}$ \\ ${ }^{1}$ Research Scholar, Department of Planning, Anna University, Chennai, India \\ 2Department of Planning, Anna University, Chennai, India , \\ ${ }^{3}$ Junior Research Fellow, Department of Planning, Anna University, Chennai, India \\ Email: 1narayana1970@yahoo.co.uk
}

Abstract

Ecological sustainability is the bottom line for social and economic sustainability. Ecological sustainability is dependent on resource consumption and resource production patterns. Land and its productivity are critical for resource production patterns. The way in which the resources are consumed leads to the "Footprint" of a given area. The ecological footprint is classified, by the inventor of footprint, Dr. Mathis Wackernagel, into land use types such as Arable land, Pasture land, Carbon dioxide land, Forest land, Built-up land, fishing ground (sea land). It is computed on per capita annual basis. The size of the footprint implies the amount of resource being consumed per unit population in an unit area. Therefore, the footprint serves as a comparable measurement for the level of resource consumption. For example, the US which records a footprint of 24 acres per capita is comparatively 12 times than Indian footprint implying that a person in US consumes 12 times of an Indian. The footprint, therefore become a famous yardstick to measure the resource consumption of an area ultimately allowing to use them to measure sustainability (comparing resources in reserve (biocapacity) vs. ecological footprint of an area. However, computation of footprint is still evolving and normally done by dividing national consumption to a per capita. If a given nation is not having variability in consumption then this tool could be directly used to compute the footprint. Whereas, country like India which is not only having a very high variability among population, but variability is observed for a given group over seasons. Therefore, the computation of footprint from Bottom-up is a rational approach, provided the researcher is ready to invest resources to collect the consumption pattern from individual households.

This paper attempts to generate Ecological footprint through Bottom-up approach for Ananganallore village situated in Gudiyattam block, Vellore district of TamilNadu, India. Local biocapacity and ecological footprint was compared to revealed level of sustainability of Ananganallore village. The study found Ananganallore has per capita Ecological Footprint of $0.292 \mathrm{gha}$ as against per capita available Biocapacity of $0.092 \mathrm{hectare}$. These results are contrasting with national per capita Ecological Footprint of 0.8 hectares and national per capita Biocapacity of 0.4 hectares. This study validates "bottom up approach" as reliable method for sustainability assessments and sub regional studies of this nature would be crucial for spatial planners for future resource planning.

Key words: Ecological Footprint, Sub-region, Resource and energy consumption, Resource production, Bottom-up approach, Biocapacity

\section{INTRODUCTION}

Sustainable development is defined as Development that meets the needs of the present without compromising the ability of future generations to meet their own needs. (1). In this study the sustainability is measured by comparing between the ecological reserve (bio-capacity) and the resource consumption (footprint). It would be not practically possible to compare between the biocapacity and the footprint unless both the parameters are converted to a common and comparable units. In this direction a pioneering work was done by Prof. William Rees and Dr. Mathis Wackernagel to convert the resource consumption and the biocapacity into standardized unit of area called "Global hectares" (2). In this paper a similar attempt is made to assess the sustainability of
Ananganallore Panchayat by computing the footprint as bottom-up approach. The Ecological footprint method applied to the study area and it represents an interesting opportunity to investigate the utility of the indicator for assessment of Local sustainability. Indeed, it allows highlighting the limitations and the qualities, and to compare and critically discuss the definitions, the assumptions it is based on, the implied methodology and the scientific robustness. Along with these theoretical aims, the entire project provides a description of the local territory, which could be easily utilized by local administrators for planning and implementing specific policies aimed at decreasing environmental impact.

The ecological footprint has been calculated considering two different spatial scales, in order to analyze in detail the relationships between local 
inhabitants and global ecosystems: (1) the Gudiyattam block; (2) the Ananganallore panchayat village (the smallest administrative Indian territorial partition ranging usually from the dimensions of a small hamlet village to those of collection of Revenue villages). This special analysis allows a deeper understanding of some geographical properties, such as spatial uniformity, territorial homogeneity, and the different configurations and spatial patterns characterizing both the allocation and the withdrawal of natural resources. Finally, the work is carefully structured in order to obtain both the global values of footprint and biocapacity, and their breakdown into different categories (ecologically productive land, consumption categories etc).

\section{A. Introduction to study area}

Gudiyattam Block is located in the northern part of the district of Vellore. It lies between $12^{\circ} 15^{\prime}$ to $13^{\circ} 15^{\prime}$ North latitudes and $78^{\circ} 20^{\prime}$ to $79^{\circ} 50^{\prime}$ East longitudes in TamilNadu. It covers an area of 220.19 Sq.Km and with a total Population of this Block is 252338 as per 2001 Census. This Block consists of 53(44 panchayat) Census Villages. Ananganallore panchayat village is part of the Gudiyattam block and has a population of 2486 (3) with land extent of 234.69 hectares as shown in map

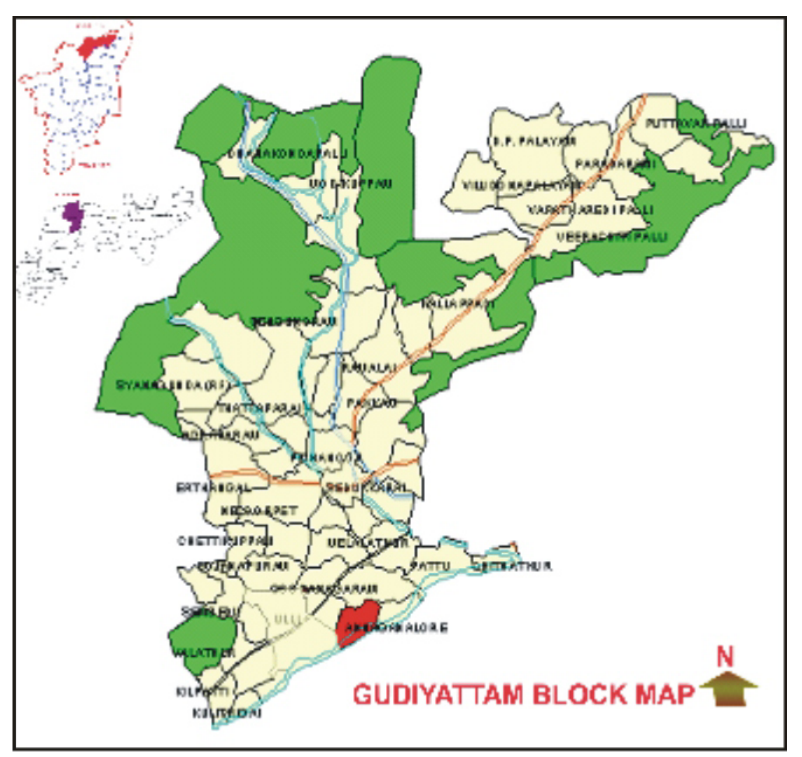

Fig. 1. Gudiyattam Block map

This block primarily comes under Agriculture. Some of the main crops raised in the block are Paddy, Ground nut, Coconut, Sugarcane, Banana, Choler and vegetables like Tomato, Brinjal, etc. Apart from agriculture; Weaving and Beedi work are other main occupation. There are 7 Weaver's societies in the block. Furthermore there are 3 spinning mills in Gudiyattam. Match work is functioning as cottage industry. Matches and Lungies produced in the block are exported to other states like West Bengal, Gujarat, and Maharashtra. Beside the above industries Beedi manufacturing is an important item of work in this block. (4)

\section{METHODOLOGY OF ECOLOGICAL FOOTPRINT COMPUTATION}

Introduced by Rees (5) and developed by Rees and Wackernagel (6), the ecological footprint is a synthetic indicator used to estimate a population's impact on the environment due to its consumptions; it quantifies the total area of the terrestrial and aquatic ecosystems necessary to supply all resources utilized in a sustainable way, and to absorb all emissions produced, always in a sustainable way.

\section{A. Ecological footprint- carrying capacity}

Ecological footprint analysis essentially inverts the logic of carrying capacity, defined as the maximum load exerted by the population of a certain species that a territory can support, without compromising its productivity. The ecological footprint focus is not to determine the maximum human population that an area can support, but to evaluate the productive territory actually used by residents, recognizing the fact that this ecosystem area does not coincide with the area where that same population lives.

\section{B. Ecological footprint-land use types}

In the classic formulation, proposed by Wackernagel and Rees (7), the ecological footprint calculation is based on the average population consumptions data that are translated into uses of productive land. The land is divided into 6 categories, following the classification of the World Conservation Union: (1) cropland; (2) grazing land; (3) forest; (4) fishing ground; (5) built-up land; (6) energy land.

Each kind of land is characterized by a different productivity and this factor has to be taken into account when calculating the ecological footprint final value. In order to make the six different kinds of land comparable with each other, the classic formulation of the ecological footprint introduces a normalization process, in which the areas of different types of land are weighted by specific equivalence factors, based on the different bioproductivities. The measurement unit for these areas is the global hectare (gha).

\section{Ecological footprint-biocapacity-sustainability}

An important part of the ecological footprint analysis of a region is represented by the calculation of its biocapacity that takes into account the surfaces of ecologically productive land located within the area under 
examination. Therefore biocapacity represents the "endowment" of ecologically productive territory that is locally available and it indicates the local ecosystems potential capacity to provide natural resources and services. This quantity can be compared with the ecological footprint, which provides an estimation of the ecological resources required by the local population. It is then possible to define an ecological balance for the territory: this balance is obtained by subtracting from the local population's needs for natural resources (the ecological footprint), the local availability of those resources (biocapacity). A positive (or negative) balance indicates a condition of ecological deficit (or surplus): this would outline a situation of unsustainability (or sustainability), in which the rate of consumption of natural resources is greater (or less) than the rate of production (regeneration) by local ecosystems (8). Therefore, an ecological deficit or surplus provides an estimation of a local territory's level of environmental sustainability or unsustainability.

\section{Ecological footprint-Applications}

Nowadays, the studies and analyses that utilize such indicators are extremely numerous and they regard very different geographical regions and spatial scales. Also, the scientific literature on this subject is quite extensive and rapidly expanding. A complete and systematic review is outside the scope of this article. We would like to mention here, along with the initial pioneering works $(9$, $10,11,12,13)$, the monographic issue of the journal Ecological Economics (14), a critical examination of the limits and potentials of this indicator. Of great relevance are also the various editions of the Living Planet Report $(15,16,17)$ that report the calculations for the world nations with populations higher than 1 million inhabitants, and that have contributed to the systematization and indepth study of the calculation formalism. Furthermore the Final Report, written for the European Common Indicators Project EUROCITIES (18) examines methods and criteria to apply the ecological footprint analysis to territories on a sub-national geographical scale, and provides 14 criteria and 5 recommendations, most of which have been strictly followed throughout the realization of the present calculations for the area of Ananganallore.

\section{E. Ecological footprint: standards}

In the year 2004, Wackernagel and collaborators founded the Global Footprint Network, a network of research institutions, scientists and users of this indicator, which aims to further improve the calculation methods and bring them to higher standard levels, therefore fostering its scientific robustness and its diffusion. Subsequently Footprint standards 2006(19) were released, and this study of Ananganallore is in conformity with standard 3.2 and 3.3 and guideline $3 b$ (sub national calculations). (20). this study uses top-level consumption component categories such as Food, housing, transport and goods as per the standards.

\section{F. Ecological footprint:" Bottom-up approach"}

Primarily this study differs from Standard 3: sub national calculations, in which top-down approach as a method was suggested for computation footprint for sub national population. The "top down approach" has a limitation of not capturing variations amongst regions and sub-regions, which is vital for regional planning and sustainability. So this study proposes an alternative methodology in which "Bottom -up approach", by aggregating local level resource and energy consumption for assessment of regional sustainability.

\section{CALCULATION METHODS AND DATA}

The ecological footprint's calculation requires a significant amount of information about natural resources consumptions, economic goods and services, industrial processes, technological and energetic efficiency, agricultural productivity, etc. While these data are generally available at a national level, it is difficult to obtain them at the regional, and especially at the local level. Therefore, in applying this study to the local level (block, Panchayat village), estimations and normalizations were applied and wherever needed a pseudo data at the panchayat and block level are applied. Indeed at this level, it was possible to find data regarding different kinds of consumptions such as number of housing by building walling/roofing material (mud house, Thatch house, terrace house, Hut, tiled house, Indira Awaas Yojana housing, other housing), energy consumption related to house holds by (firewood, coconut shells, kerosene, Liquefied petroleum gas) was obtained. (Energy consumptions related to transportation (Petrol, diesel, fuel oil, Liquefied petroleum gas) were estimated from panchayat level data.

\section{A. Direct measurement of consumption}

This study has made a novel attempt by measuring consumption directly through random sampling survey of households in the study area. The size of the sample is 3\% of the no. of households in the study area. The average household consumption of sample was obtained and extrapolated to generate total panchayat consumption. The sample questionnaire contained primary ecological footprint consumption component types such as i) food, ii) housing, iii) transportation, iv) goods. The subclassification of primary level components was as shown in Table 1. 
Table.1. Classification of Primary footprint consumption component types

\begin{tabular}{|c|c|c|c|c|}
\hline S.No & $\begin{array}{l}\text { Primary } \\
\text { component }\end{array}$ & $\begin{array}{l}\text { Ist level } \\
\text { classification }\end{array}$ & Sector & Il level classification \\
\hline \multirow[t]{10}{*}{1} & Food & Food & Household & Animal based \\
\hline & & & Household & Dairy based \\
\hline & & & Household & Cereals \\
\hline & & & Household & Others \\
\hline & & & Household & Pulses \& spices \\
\hline & & & Household & Oils \\
\hline & & & Household & Fruits \\
\hline & & & Household & Vegetables \\
\hline & & & Household & Cotton consumption \\
\hline & & Marine food & Household & Fish, prawn \\
\hline \multirow[t]{4}{*}{2} & Housing & $\begin{array}{l}\text { Building, } \\
\text { Embodied } \\
\text { energy }\end{array}$ & All sectors & Building material walling and roofing \\
\hline & & Timber & Household & Fire wood, paper \\
\hline & & Direct energy & Household & Liquefied Petroleum Gas cylinder, kerosene, \\
\hline & & & All sectors & Electricity \\
\hline \multirow[t]{2}{*}{3} & Transportation & $\begin{array}{l}\text { Embodied } \\
\text { energy }\end{array}$ & Household & $\begin{array}{l}\text { Transporting food \& marine food, Transporting } \\
\text { paper, for transporting Liquefied petroleum gas } \\
\text { cylinder, kerosene, for transporting diesel and } \\
\text { petrol, transport. }\end{array}$ \\
\hline & & Direct energy & All sectors & $\begin{array}{l}\text { Liquid fossil fuel consumption by Tractor, power } \\
\text { tiller, sprayer, two-wheeler. }\end{array}$ \\
\hline 4 & Goods & $\begin{array}{l}\text { Embodied } \\
\text { energy }\end{array}$ & $\begin{array}{l}\text { Household \& } \\
\text { part sectors }\end{array}$ & $\begin{array}{l}\text { Household products, aluminum products, Iron \& } \\
\text { steel products, Brass products, Plastic products, } \\
\text { Electronic products, Electrical products, } \\
\text { Stainless steel products, wood furniture, } \\
\text { synthetic textiles, Telecom products, Tractor, } \\
\text { power tiller, sprayer, two wheeler, four wheeler, } \\
\text { bicycle. }\end{array}$ \\
\hline
\end{tabular}

Special attention has been given to the calculation of the energy consumption ecological footprint, which represents the greatest contribution to the final result. We have therefore referred to several different data sources from which it was possible to deduce the consumption values for solid, liquid, gas combustibles, for electric energy (either thermal, hydroelectric, and obtained from other renewable sources), identified according to their final uses.

Biodiversity is accounted in the calculation of biocapacity available to humans in the Ananganallore panchayat village using the standard (but not scientifically well-founded) approach. This method (Wackernagel and Rees, 1996) requires that allocation of $12 \%$ of the total productive land and water area to provide reserve areas for local biodiversity conservation. In calculating both the ecological footprint and the biocapacity, use of the Living Planet Report 2003 for the equivalence and yield factors; this implies that the yield factors used to weight Ananganallore's biocapacity do not reflect the specific productivities of Ananganallore's ecosystems but the average national value. The main data sources are reported in Table 2.

\section{RESULTS}

\section{A. Different methods for reading the results}

When structuring the calculations of a territory ecological footprint and biocapacity, it is important to ensure an adequate degree of disaggregation so as to allow the analyst to derive a multiple and insightful reading of the final data. We have therefore elaborated our results in different ways, summarized as follows. 
Table 2. Data sources, types of Ananganallore

\begin{tabular}{|c|c|c|c|}
\hline S.No & Data & Source & Year \\
\hline \multirow[t]{2}{*}{1} & Food consumption & Primary household survey & 2006-07 \\
\hline & Marine food consumption & Primary household survey & $2006-07$ \\
\hline \multirow[t]{6}{*}{2} & Housing & & \\
\hline & $\begin{array}{l}\text { Type and number of } \\
\text { houses }\end{array}$ & Panchayat development report, Ananganallore & 2004 \\
\hline & Fire wood, paper & Panchayat development report, Ananganallore & 2004 \\
\hline & $\begin{array}{l}\text { Coconut shells \& } \\
\text { agriculture residue }\end{array}$ & Primary household survey & $2006-07$ \\
\hline & $\begin{array}{l}\text { Liquefied Petroleum Gas } \\
\text { cylinder, kerosene }\end{array}$ & Panchayat development report, Ananganallore & 2004 \\
\hline & Electricity & $\begin{array}{l}\text { Office of the Executive engineer, Tamilnadu Electricity } \\
\text { Board, vellore,\& Panchayat development report, } \\
\text { Ananganallore }\end{array}$ & 2004 \\
\hline \multirow[t]{3}{*}{3} & Transportation & & \\
\hline & Embodied energy & Primary household survey & $2006-07$ \\
\hline & Direct energy & $\begin{array}{l}\text { Panchayat development report, Ananganallore, Primary } \\
\text { household survey. }\end{array}$ & $\begin{array}{l}2004,2006- \\
07\end{array}$ \\
\hline \multirow[t]{2}{*}{4} & Goods & & \\
\hline & Embodied energy & $\begin{array}{l}\text { Panchayat development report, Ananganallore, Primary } \\
\text { household survey. }\end{array}$ & $\begin{array}{l}2004,2006- \\
07\end{array}$ \\
\hline
\end{tabular}

\section{Aggregated results}

When analyzing a sub-national area, the ecological footprint final value cannot be particularly significant if considered in itself. However, when compared with other quantities, such as biocapacity on different spatial scales, this value may offer important insights about the "level of sustainability" of the examined territory and about the scales that characterize the level of natural resources appropriation. Therefore the present study compares ecological footprint with the following quantities:

\subsection{Local biocapacity}

A comparison between the ecological footprint and the local biocapacity (both as per capita and as total values) allows evaluating a local ecological balance, and therefore the ecological deficit or surplus relative to the given territory. This information provides an estimate of the amount of ecological resources used by residents, identifying how much is drawn from local ecosystems and how much comes from imported land.

\subsection{Average Block (region) biocapacity}

This comparison allows estimating the local per capita ecological footprint in the regional context, comparing it with the average amount of land available per capita at the Block level.

\subsection{Average national biocapacity}

The comparison between the local per capita ecological footprint and the average national per capita biocapacity allows connecting the consumption levels of natural resources, and therefore the lifestyle of the inhabitants of the Ananganallore panchayat, with the national sustainable consumption level, represented by the average amount of land available per capita in the country.

\subsection{Average world biocapacity}

The comparison between the local per capita ecological footprint and the average global per capita biocapacity allows connecting the consumption levels of natural resources, and therefore the lifestyle of the inhabitants of the Ananganallore panchayat, with the global sustainable consumption level, represented by the average amount of land available per capita in the world.

\section{Disaggregated results}

We have chosen to disaggregate the results according to the following categories: 
Consumption: We refer to the classic subdivision, first proposed by Wackernagel and Rees (1996) that focus on the causes (the different types of consumption) that require the use of natural resources.

Ecologically productive land: These categories have also been proposed by Wackernagel and Rees (1996), and they refer to the types of ecosystems that are affected by anthropic impacts.

\section{Spatially disaggregated results}

This consists of a geographical analysis that considers the territory on different spatial scales. In the present case, the calculations have been performed on the panchayat and block levels. This allows highlighting on the one hand the areas of spatial uniformity, on the other hand the possible heterogeneous configurations that characterize the territory in the allocation and withdrawal of natural resources. This specific analysis provides a further level of insight when combined with other kinds of geographical information such as economic, demographic, social, etc.

\section{B. Aggregated results analysis}

Table 3 reports the per capita values of the ecological footprint (disaggregated according to ecologically productive land categories) and those of the biocapacity and the ecological deficit for the Ananganallore panchayat, compared with those for nation and for the world

\section{Comparison with local biocapacity}

As mentioned above, we have started our analysis by comparing the local biocapacity that calculates the area of the ecologically productive land in the Ananganallore, with the ecological footprint, which estimates the ecological resources demanded by the local population. The local bioproductivity is able to cover only 0.092 out of the 0.292 gha per capita of ecological surface (i.e., "ecosystems") required by the inhabitants of the Ananganallore Panchayat. The result is an ecological deficit, of about 0.2 gha per capita, which is a significant deficit. This means that around $68.5 \%$ of the Primary demand of natural resources by local inhabitants could be achieved only through imports from other regions. In order to tackle this issue, we have extended our analysis of the ecological balance to the individual categories of ecologically productive land. Fig. 1 shows that the Ananganallore has a high level of net importer of economic goods and services related to all land uses, except cropland, in which imports are marginal.

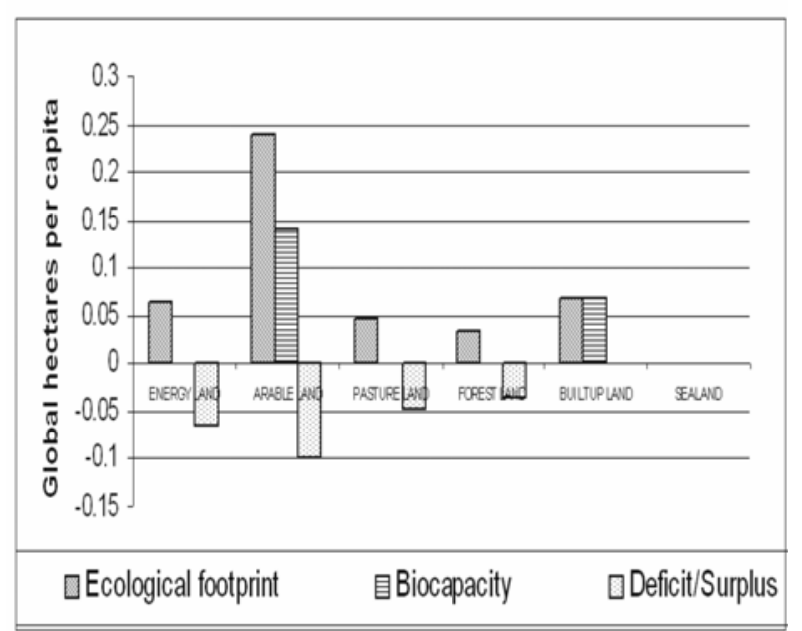

Fig. 2. Ecological Footprint, Biocapacity and Deficit/surplus per capita of Ananganallore

Per capita values of the ecological footprint (disaggregated according to ecologically productive land categories) of the biocapacity and of the ecological deficit for the Ananganallore, compared with those for India and for the world (data from Living Planet Report 2006, data reported for the year 2003). All data are in gha per person.

A further interesting step would be extending this analysis to incorporate also trade flows for each category of productive land. This would allow not only to estimate the net value of the import/export, but also to reconstruct all the individual input and output flows, thus allowing diagnosing the possible occurrence of local ruinous practices. We could not perform this kind of calculation due to the lack of data regarding the economic goods and services flows through the boundary of the Ananganallore panchayat.

\section{Comparison with the average Block biocapacity:}

By comparing the ecological footprint of Ananganallore (0.292gha) with Gudiyattam block biocapacity (0.092gha), we find that the ecological footprint for the Ananganallore panchayat is higher leading to a deficit of (0.2gha). In order to evaluate this result, it is important to consider that the two values are not fully comparable, as we are working with two studies on quite different scales (Regional-Local) and therefore we utilize data, methods and approximations that can vary greatly. Nonetheless, keeping these limitations in mind, the two values can be read in parallel, leading to the conclusion that the lifestyle (and therefore the consumption trend) that characterizes the Ananganallore inhabitants of rural area is more close to urban level of consumption. What Changes in a very notable manner is the result of the ecological balance: while the Ananganallore is characterized by an 
Table.3. Comparison of Ananganallore Ecological Footprint and Biocapacity with country and globe

\begin{tabular}{|l|l|l|l|l|l|l|l|l|l|}
\hline & $\begin{array}{l}\text { Energy } \\
\text { land } \\
\text { gha }\end{array}$ & $\begin{array}{l}\text { Crop } \\
\text { land } \\
\text { gha }\end{array}$ & $\begin{array}{l}\text { Grazing } \\
\text { land } \\
\text { gha }\end{array}$ & $\begin{array}{l}\text { Forest } \\
\text { land } \\
\text { gha }\end{array}$ & $\begin{array}{l}\text { Built-up } \\
\text { land } \\
\text { gha }\end{array}$ & $\begin{array}{l}\text { Fishing } \\
\text { ground } \\
\text { gha }\end{array}$ & $\begin{array}{l}\text { Ecological } \\
\text { footprint } \\
\text { gha }\end{array}$ & $\begin{array}{l}\text { Biocapacity } \\
\text { gha }\end{array}$ & $\begin{array}{l}\text { Ecological } \\
\text { deficit } \\
\text { gha }\end{array}$ \\
\hline Ananganallore & 0.05 & 0.13 & 0.06 & 0.032 & 0.009 & 0.0003 & 0.292 & 0.092 & -0.20 \\
\hline India $^{*}$ & 0.26 & 0.34 & 0.00 & 0.08 & 0.04 & 0.04 & 0.8 & 0.4 & -0.4 \\
\hline World $^{*}$ & 1.14 & 0.49 & 0.14 & 0.23 & 0.08 & 0.15 & 2.23 & 1.78 & -0.45 \\
\hline
\end{tabular}

an ecological deficit of around 0.20Gha, values for gudiyattam show that the average biocapacity can only cover $31.5 \%$ of the Ananganallore ecological footprint, leaving an ecological deficit of $68.5 \%$ on per capita basis. Such percentages demonstrate a substantially unique situation for both Ananganallore and gudiyattam, characterized by substantial levels of import of natural resources from other regions. It should, however, be noted that the Ananganallore exhibits a distinct ecological behavior, not really because of its high ecological footprint, but because of its low levels of biocapacity per capita, correlated to the productivity of land that characterizes the Gudiyattam territory.

\section{Comparison with the average national biocapacity}

The ecological footprint for the Ananganallore panchayat is significantly lower and typical of rural settlement, than the average Indian footprint value by $36.5 \%$. This indicates that life style (and therefore the consumption trend) that characterizes the Ananganallore inhabitants; Ecological footprint of (0.292gha) is significantly lower than national level biocapacity (0.4gha). The footprint of Ananganallore, when compared with national biocapacity is highly sustainable. This implies that the inhabitants of the Ananganallore territory on average consume ecological resources and goods that are with in the balanced sustainable withdrawal rates on the national level, therefore contributing to the trend of sustainability and enhancement of the National natural capital.

Ananganallore is characterized by a ecological deficit of around $0.20 \mathrm{gha}$, values for India show that the average biocapacity can only cover $50 \%$ of the national ecological footprint, leaving an ecological deficit of $50 \%$. Such percentages demonstrate a substantially different situation for both Ananganallore and India, characterized by high levels of import of natural resources from other regions and abroad.

\section{Comparison with the average worldwide biocapacity}

Here we compare the Ananganallore situation with the average worldwide ecological footprint and biocapacity, reported in Table3.
This shows, primarily, the great difference between the average worldwide ecological footprint (2.23 gha per capita) and the one of the Ananganallore panchayat; the latter being approximately one eighth, a definitely low value, and hence indicates very strong sustainability.

This comparison of the Ananganallore territory with average worldwide data allows us as well to highlight the vast difference between the ecological footprint of the Ananganallore panchayat and the average worldwide biocapacity, which amounts to the value of 1.48 gha per capita. This implies that the inhabitants of the Ananganallore territory consume, on average, a much lower amount of ecological resources and goods than the sustainable withdrawal rates on the worldwide level, therefore contributing to the trend of strong sustainability and enhancement of the global natural capital.

\section{Disaggregated results analysis}

1. Ecological footprint and ecologically productive land categories. Fig. 2 shows the ecological footprint of the Ananganallore panchayat disaggregated according to the categories of ecologically productive land. It is immediately evident that a vast percentage of land is utilized as arable land $(44.23 \%)$, followed by Pasture land $(23.42 \%)$. Interestingly, the energy land footprint is only $17.83 \%$ of the total footprint.

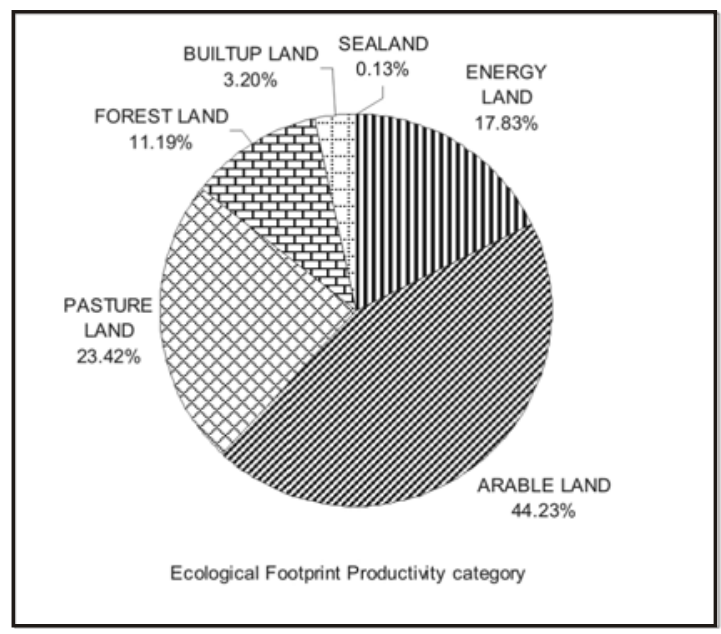

Fig. 3. Ecological Footprint Per Capita -Distribution By Land Use -Percentage Wise 
In general, one may say that the Ananganallore panchayat follows a trend that is quite distinct from other industrialized areas, in which energy land footprint represents between one and two thirds of the entire value of the ecological footprint.

Within the energy land, we have accounted for both direct energy use and embodied energy use. Direct energy use computation was done for Household electricity consumption, Liquified Petroleum Gas and Kerosene, Liquid fossil Fuel consumption of vehicles (farm equipment) operating in the study area. Embodied energy computation for housing, transport, goods and embodied energy in transporting food, goods, paper and liquid fossil fuel was done.

\section{Ecological footprint and consumption categories}

The disaggregating of the ecological footprint according to the consumption categories allows focusing more effectively on the origin of different contributions, and therefore to better investigating the causes of

environmental unsustainability. Fig. 3 reports such subdivisions; it may be observed that the greatest contribution ( $40 \%$ ) is caused by housing $(43 \%)$ followed by food consumption (41\%), goods (14\%) and transport $(2 \%)$.

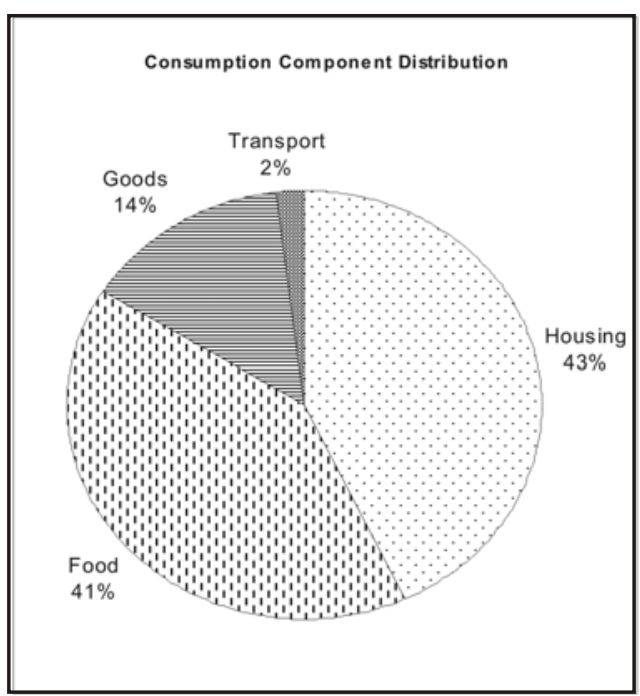

Fig. 4. Ecological Footprint Per Capita-Consumption Category-Percentage Wise

It is interesting to further investigate the categories that contribute the most to the ecological footprint, as this may help to individuate the real causes of environmental impact and induce the undertaking of corrective actions. By matching the information included in the consumption. Categories to that included in the ecologically productive land categories, we demonstrate (Fig. 4) that the types of consumption that most contribute to the energy component of the ecological footprint are housing $(0.037$ ha) amounting to $62 \%$, goods (0.02 ha) and transport (0.0024ha) amounting to $34 \%$ and $4 \%$ respectively per capita.

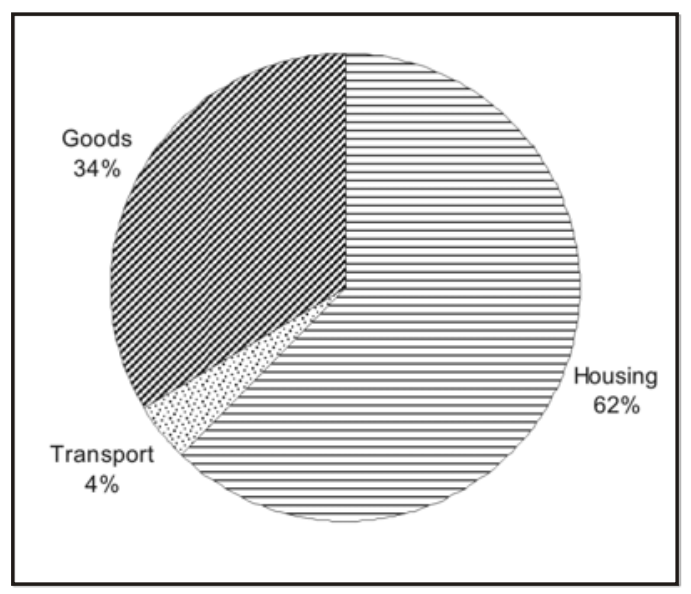

Fig. 5. Carbon Dioxide Land Footprint Per CapitaEnergy Consumption -Sector Wise-Percentage Wise

Furthermore, from Fig. 4, one can deduce that the next to Housing energy consumption goods component represents the greatest contribution of all the consumption categories; in particular for Direct Energy consumption (35\%), embodied energy consumption $(64 \%)$ and less than $1 \%$ for transport embodied energy for imported commodities as shown in Fig.5.

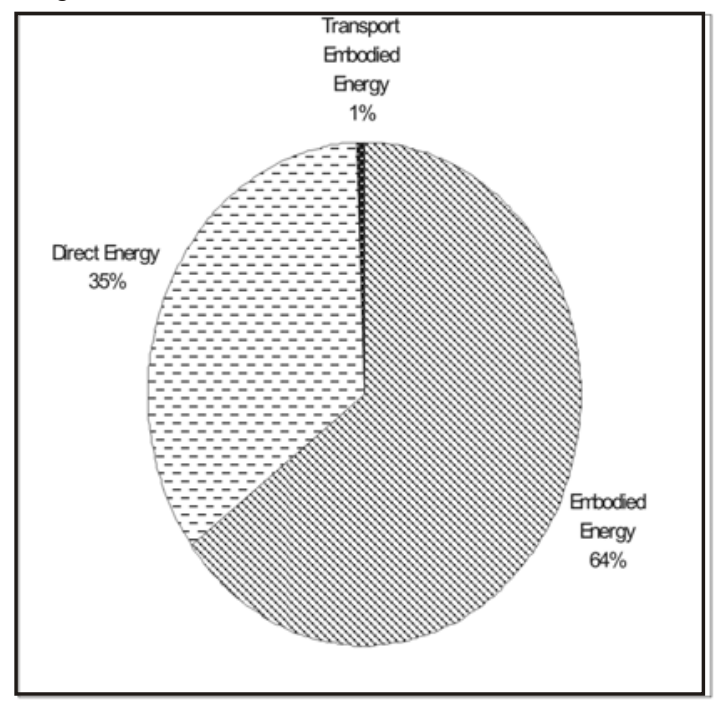

Fig. 6. Carbon Dioxide Land Footprint Per CapitaEnergy Consumption -Distribution-Embodied, Direct And Transport Embodied Energy 
Amongst, direct energy consumption categories Total settlement electricity consumption footprint per capita amounts to $(58 \%)$, Household energy- Liquefied Petroleum Gas (26\%), Household energy- kerosene $(16 \%)$ as shown in Fig 6.This analysis is useful in concluding that decentralized power generation through renewable sources would reduce the Carbon dioxide land required.

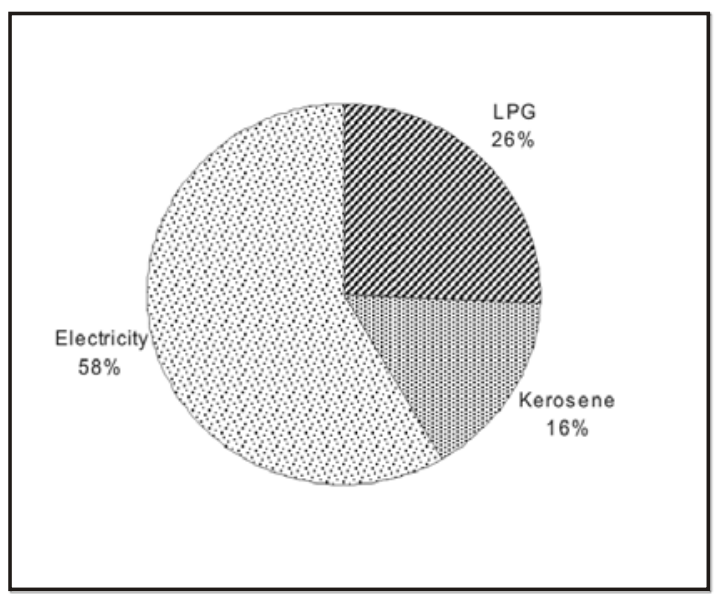

Fig. 7. Carbon Dioxide Land Footprint Per Capita-Direct Energy Consumption -Source Wise

It is possible to analyze in detail Carbon dioxide emission component of electricity, by highlighting how energy sources sector wise are contributing to the Carbon dioxide emissions such as domestic (56\%), agriculture $(16 \%)$, streetlights $(15 \%)$, commercial $(10 \%)$, Industrial $(1 \%)$, others (2\%) as shown in Fig 7.

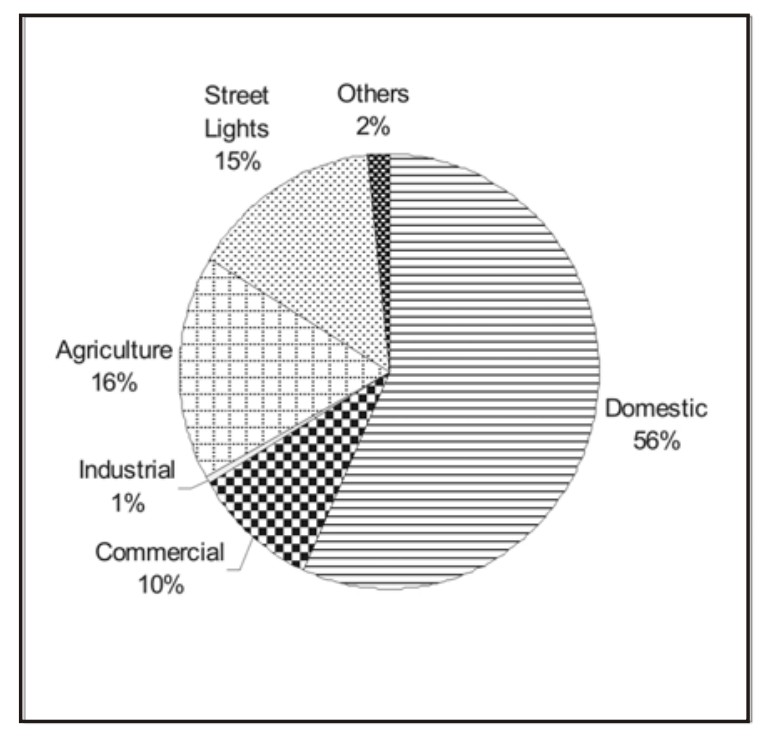

Fig. 8. Carbon dioxide land footprint per capita -direct energy consumption -electricity - sector wise

\section{CONCLUSIONS}

This article has presented the results of the analysis of the ecological footprint and the biocapacity of the Ananganallore panchayat village. This is a particularly interesting area because, as compared to the national biocapacity, an almost matching balanced footprint characterizes it in per capita terms, though local biocapacity could not match the demand of natural resources by local inhabitants and could be achieved only from imports. The calculations have been performed in such a way as to ensure a high range of possible desegregations of the final results, according to categories of productive land and consumption

Along with this information, this study has been structured to investigate the geographic properties in relation to the distribution and the use of ecological resources. The analysis has therefore been carried out at different spatial scales: Local, block, nation, and world.

The bottom up approach methodology, which was used in this study, is unique and through exhaustive and extensive primary surveys and local data collection, and adapted panchayat level data and assessed footprint. The calculations have used $80 \%$ of the data from field investigations, $15 \%$ from secondary sources and $5 \%$ proxied (Electricity) from national/state level data.

This study has validated the "Bottom up approach" methodology to assess regional sustainability. This study has assessed level of sustainability (deficit /surplus) by direct measurement of consumption of renewable and nonrenewable resources by Ananganallore residents by using Footprint- biocapacity technique. This study has resulted in detailed data on consumption of renewable resources and non-renewable resources.

Finally, we remind that the results obtained with the analysis of the ecological footprint of Ananganallore panchayat are planned to be included in the more extensive Gudiyattam Block ecological footprint and Regional sustainability studies. By integrating these results to those coming from the other panchayat sustainability studies, it is possible to delineate a coherent and exhaustive quantitative picture of the complex relationships between society and environment in the Gudiyattam block and to provide the public administrations and decision makers with an overall perspective on the problem of resources and natural capital consumption. 


\section{ACKNOWLEDGEMENT}

We sincerely acknowledge NRDMS division of Department of science and Technology, Government of India for funding R \& D project titled "Development and testing tools for quantitative assessment of sustainability, a case of Gudiyattam Block, Vellore District, TamilNadu" during 2006-

08 . This research paperis generated from the project.

\section{REFERENCES}

[1] WCED, 1987, our common future, 1987, Brundltland commission report.

[2] A resource flow and Ecological footprint analysis of Scotland, 2004, www.scotlands-footprint.com

[3] Earth Trends 2003. (Climate and Atmosphere- India) http://earthtrends.wri.org

[4] Block statistical handbook, 2004-05, Gudiyattam. A Report by Office of the Assistant Director of Economics \& Statistics, Vellore.

[5] Rees, W.E., 1992. Ecological footprints and appropriated carrying capacity: what urban economics leaves out. Environment and Urbanization 4 (2), 121-130.

[6] Rees, W.E., Wackernagel, M., 1994. Ecological footprints and appropriated carrying capacity:

measuring the natural capital requirements of the human economy. In: Jansson, A., Hammer, M., Folke, C., Costanza, R. (Eds.), Investing in natural capital: the ecological economics approach to sustainability. Island Press, Washington, pp. 362-390

[7] Wackernagel, M., Rees, W.E., 1996. Our ecological footprint. Reducing Human Impact on the Earth. New Society Publisher, Gabriola Island, Canada.

[8] Rees, W.E., 1992. Ecological footprints and appropriated carrying capacity: what urban economics leaves out. Environment and Urbanization 4 (2), 121-130.

[9] Rees, W.E., 1995. Achieving sustainability: reform or transformation? Journal of Planning Literature 9, 343-361.
[10] Rees, W.E., 1996. Revisiting carrying capacity: areabased indicators of sustainability. Population and Environment 17, 195-215.

[11] Rees, W.E., Wackernagel, M., 1996. Urban ecological footprints: why cities cannot be sustainable (and Why they are a Key to Sustainability). Environmental Impact Assessment Review 16, 223-248.

[12] Wackernagel, M., Rees, W.E., 1996. Our ecological footprint. Reducing Human Impact on the Earth. New Society Publisher, Gabriola Island, Canada.

[13] Ecological Economics, 32 (3), 2000, 341-394 Energy information Administration, country analysis briefs, India, 2005, http://www.eia.doe.gov.

[14] WWF, UNEP- WCMC, 2000. Living Planet Report 2000. World Wildlife Found Editor

[15] WWF, UNEP-WCMC, 2002. Living Planet Report 2002. World Wildlife Found Editor.

[16] WWF, UNEP-WCMC, 2004. Living Planet Report 2004. World Wildlife Found Editor.

[17] Lewan, L., Simmons, C., 2001. The use of ecological footprint and biocapacity analyses as sustainability indicators for sub-national geographic areas; Annexure 1,A recommended way forward, European common indicators project, Final report 27thAugust, 2001.

[18] Footprint standards 2006 , http:www.footprintstandards.org

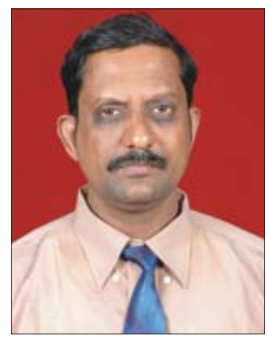

Mr. K.A. Narayana is a Research Scholar at The School of Architecture and Planning, Anna University and an Assistant Professor at the Department of Architecture, Sathyabama University, Chennai. A Postgraduate from School of Architecture and Planning, his areas of interests are Sustainability Assessment, Regional Environmental Planning and Local level planning. 